\begin{tabular}{|c|c|}
\hline \multirow{3}{*}{ 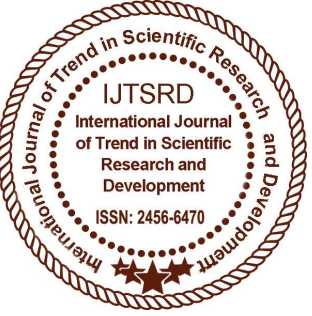 } & $\begin{array}{l}\text { International Journal of Trend in Scientific } \\
\text { Research and Development (IJTSRD) }\end{array}$ \\
\hline & International Open Access Journal \\
\hline & ISSN No: 2456 - 6470 | www.ijtsrd.com | Volume - 2 | Issue - 5 \\
\hline
\end{tabular}

\title{
Women Empowerment Through Cooperative In Anambra State. (A Study Of Awka South Local Government Area, Anambra State Nigeria)
}

\author{
Okafor Ogochukwu ${ }^{1}$, Nwankwo Frank O. \\ ${ }^{1} \mathrm{Ph} . \mathrm{D},{ }^{2}$ Professsor
}

Department of Cooperative Economics and Management, Nnamdi Azikiwe University, Awka, Anambra State, Nigeria

\section{ABSTRACT}

The study evaluated how Cooperatives could be used to empower women in Awka South local Government Area of Anambra State. The researcher used Frequency distribution table and percentage to turn the qualitative characteristic into numerical forms. Likert scale analysis was used to examine the perception of member on how cooperative services have brought about an enhancement to their economic well-being as represented by income. Further analysis was under taken to measure the effects of cooperative services such as credit extension, input supply, marketing, processing agricultural production on their income. To accomplish this, a multiple regression analysis was employed. Evidence from the study revealed that educational level has marginal contribution of -317.032 with a $t$ - ratio of -2.009 which is significant at 5\% level of significance. Family size has marginal contribution of -854.265 with t-ratio of -1.682 which is significant at $1 \%$ level of significance. The value of agricultural product marketed through women cooperative has a marginal contribution of .977 . The $\mathrm{t}$ - value is 23.728 which are significant at $1 \%$ level. This result also shows that marketing through cooperative is positively related to income of the members. The value of agricultural product processed through women cooperative has a marginal contribution of .008 . The $\mathrm{t}$-value is 1.346 which is highly significant at 1 and $5 \%$ level of probability. This result also shows that value of processed product is positively related to income, as the processed product increases, income increases.
The amount of input procured has a marginal contribution of .173 . The $t$-value is 4.037 which are highly significant at $1 \%$. Thus there is a high degree contribution of input procured by the members of women cooperative to their income. This result also shows that input has a positive relationship with income that is as the amount of input increases, income level increases. Thus input is relatively significant determinant of income of women cooperative societies in Awka south. In spite of the contributions cooperatives in empowering women in the study area, evidence from the study revealed that cooperatives were constrained by many challenges. In order/to strengthen cooperatives improve on the services they provide to their members, Government should aid those women cooperative by providing them with loans and grants as fund is the life wire of any business. Cooperative should encourage and ensure that the cooperative extension officers in the area carry out their duties efficiently and effectively so as to encourage those women cooperative in the rural area.

Keywords: Empowerment, Cooperative, Empowering through cooperative.

\section{INTRODUCTION}

\section{Background of the Study}

In Nigeria, women play a dominant role in agricultural production. According to FAO (1987), women make up $60 \%-80 \%$ of the agricultural labour 
force and depending on the region produce two - third of the food crops. The rapid increase of women participation in agriculture can be traced to male migration from rural to urban centres in search of white collar job ( Chilokwu and Obi; 2009; Onugu 2006). Their participation in agriculture varies from one ecological zone to another depending on region, tribe and culture. However, their farm activities covers kitchen, garden, vegetable production, seedling, weeding, harvesting, processing, storage and aspects of nutrition, care of poultry and other livestock (FAO, 1990). The wide spread assumption that men make the management decisions have prevailed consequently, agricultural extension services in Nigeria have traditionally focused on men and farm produce needs, while neglecting the female half of the production force, women significant contribution to food production has been well documented and yet full recognition of the range of agricultural activities under taken by them in food production is lacking. This is verified by the wholly inadequate allocation of resources and services to women production activities. (FAO, 1987)

In recent times, there is a grown recognition of the need to improve both the agricultural education and extension work with rural women. This is necessary as both a fundamental right and as a matter of good developmental sense. As stated by FAO (1990) the lost benefit analysis showed that investing in the education of females has the highest rate of return any possible type in developing countries.

It is clear that woman's choices about activities and their ability to increase income are seriously constrained by gender inequalities in access to other resources for investment, responsibility for household substance expenditure. Lack of time because of unpaid domestic work and low levels of mobility, constraints on sexual violence which limit access to markets in many culture. Women are not economically empowered, this was an assumption that women's education ends in kitchen and child bearing. As a result, they are economically and financially handicapped which denies them assets to wealth accumulation that will aid further production. In some culture, women are not allowed to participate in economic activities such as farming, their relegated position in the societies do not enable them to influence labour like their male counterparts. The aim of this study to examine the socio-economic characteristics of members of women cooperative in the area, to determine the activities and functions of women cooperative in the area and assess the effect of cooperative activities and functions on the income and standard of living of members of women cooperative in the area.

\section{RESEARCH QUESTIONS}

1. What are the socio-economic characteristics of members of women cooperative in the area?

2. What are the activities and functions of women cooperative in the area?

3. Do cooperative activities $\backslash$ functions have effect on the income and standard of living of members of women cooperative?

4. What are the recommendations on the ways of strengthening the empowerment of women through cooperative in the area?

\section{The Concept of Empowerment}

Empowerment is a construct shared by many disciplines and arenas; community development, psychology, education, economics, and studies of social movement, and organizations among others. How empowerment is understood varies among these perspectives.

In recent empowerment literature, the meaning of the term empowerment is often assumed rather than explained or defined. Rapp port (1984) has noted that it is easy to define empowerment by its absence but difficult to define in action as it takes on different form in different people and contexts.

Empowerment is better known and understood when we see it in people with whom we are working and for programme of evaluation. Cheryl (1999) has noted that the term empowerment has no clear definition especially one that could cross- disciplinary lines. He sees empowerment as a multi-dimensional social process that helps people gain control over their own lives. Empowerment is a process that challenges our assumptions about the way thing is and can be. It challenges our basic assumptions about power, helping, achieving, and succeeding. To begin to clarity the concept of empowerment, we need to understand the concept broadly in order to be clear about how and why we narrow our focus to women empowerment through cooperative. He further said that the core of the concept of empowerment is the idea of power. The possibility of empowerment depends on two things. First, empowerment requires that power can change, if power cannot change, if it is 
inherent in position or people, then empowerment is not possible, nor is empowerment conceivable in any meaningful way. In other words, if power can change, then empowerment is possible. Second, the concept of empowerment depends upon the idea that power can expand. This second point reflects our common experiences of power rather than how we think about power.

Wikipedia free encyclopaedia defines empowerment as increasing the spiritual, political, social, or economic strength of individuals and communities. It often involves the empowered developing confidence in their own capabilities.

Sociological empowerment often addresses members of groups that social discrimination processes have excluded from decision-making processes through, for example, discrimination based on disability, race, ethnicity, religion or gender. Empowerment as a methodology is often associated with feminism.

Nevertheless, Abdalla (1999) is of the opinion that empowerment is a complex and often misunderstood concept. It is located within the discourse of community development and is connected to concept of self-help participation, networking and equity. While it has acquired a considerable aura of "respectability", even "social status" within the vocabulary of development, it has not yet acquired a socially agreed content. It is also one of those concepts whole full implications people do not realized when they use it.

He further said that empowerment has evolved within the development discourse. It has dethroned the term "participation", which lost some of its currency since the 1980s.Empowerment came into vogue in response to the situation, where people could "participate" in a project without having the power to decide on the critical issues to the project. However, empowerment appears to mean different things to different people. He noted that empowerment is supposed to bring closer those who hold power and those who are powerless. Empowerment moves the powerless into positions of power and makes those at the higher levels of power accept sharing power with them.

More so, he said that empowerment generally means engaging the relevant stakeholders in a given process by applying the principles of inclusiveness, transparency and accountability. As such, the empowerment concept goes beyond the notions of democracy, human right and participation to include enabling people to understand the reality of their environment (social, economic, political, ecological and cultural) and to take the necessary actions to improve their well-being.

The fundamental goal of empowerment is to help individuals within the society to improve the quality of their own lives and share equality in the benefit of economic growth. Growth that depends on constant infusions of grants or subsidized financing from government or other donors is inherently unsustainable. Empowerment is about helping people unleash their creative and productive energies to achieve sustainable growth and continuous improvement in their living standard. To empower means either to strengthen ones belief in his ther selfefficacy or to weaken ones belief in personal powerlessness. Therefore, any real empowerment must be "self-empowerment". There must be an internal urge to influence and control (Conger and Kanungo 1988). People are empowered when they feel an enhancement of their abilities to control, influence or cope with their social or economic roles.

The motivational dimension of empowerment involves various factors:

1. People will not be empowered if they do not want to be. They have to be motivated intrinsically they have to believe in the merits and prospects of empowerment.

2. Empowerment is about creating the conditions conducive to enhancing motivation to perform by developing the person's sense of selfdetermination and enhancing his ther belief in selfefficacy.

3. Empowerment entails providing the ability to perform the necessary skills knowledge, and so on. It also entails giving a fair opportunity to perform.

Government therefore, cannot (and should not) impose empowerment from above. Empowerment has to be an objective the individual must strive to achieve. Government can (and should) ensure equal access to economic opportunities, but is up to each citizen to take advantage of them or to ignore them crabbing hands for too long create dependency and kill the drive to do things on one's own. It must be recognized, however, that although equal opportunities can be created for citizens equal out 
comes cannot be guaranteed because people respond differently to the same incentives.

\section{The Rationale for Empowerment}

As indicated above, the concept of empowerment goes one step further than participation because people can participate in a given process without having the power to make critical decisions related to the activity or process they are involved in. what remains ambiguous in most discussion of empowerment is the question of self-reliance. How much must people do for themselves? The achievement of personal goal may require at least the following Identification of need.

1. Identification of option or strategies.

2. Decision or choice of action

3. Mobilization of resources; and

4. The action itself.

At one extreme, the conservative use of empowerment may be restricted to situations of total self-help. According to view, empowerment requires that all the above steps be completed by the participants themselves, with minimal outside intervention (or material support). At the other extreme is the view that the only thing required for empowerment to occur is participation in decision-making. In terms of the steps required to achieve a personal goal, empowerment might mean consultation with the person or the community in the identification of needs and over the choice of options. Everything else is done on behalf of the empowered person by other professional persons. This kind of approach to empowerment attracts the critique of tokenism. Such an approach fails to recognize that as long as others who have access to resources control the process, then the process is actually disempowered.

For groups or communities to be empowered, they must adopt a more collective and more political stance towards external change agents, and they must use that conditions under which development takes place. In that sense, empowerment can be said to involve three kinds of power (Friedman, 1992).

1. Social power, which is concerned with access to productive skills, material good and information.

2. Political power, which concerns the involvement of individuals in the decision-making processes which affect their lives. Political power is not limited to formal elections, but through collective actions the interests of those organized may be promoted in the absence of, or in addition to any formal political process.

3. Psychological empowerment is often the product of social and political power, but it cannot be reduced to either. In fact, lack of psychological empowerment will render all other forms of empowerment ineffective. Psychological empowerment is, therefore, a necessary (but not sufficient) condition for economic empowerment.

Economic empowerment means that disempowered people takes responsibility for their own material gain an on-going basis and become managers of their own development. As citizens gain awareness and selfconfidence, they realize that they can be self-reliant in pursuing their own economic dreams. Empowerment is a process of validation and encouragement. This means providing incentives and opportunities for making business. It does not mean, however, that people should be shielded from the consequences of making economic decisions. Nor should it create price distortions and increases inefficiency in the economy.

For the purpose of this paper, our focus is on economic empowerment of women through cooperative society. More generally, economic empowerment strategies include six main categories:

1. Financial intervention - to assist local business activities (increased access to credit).

2. Enterprise development - increased access to skill, business and management training and improved production technologies.

3. "Marketing strategies for locally produced goods services (increased access to markets).

4. Bargaining strategies - for higher wages, better working conditions etc for the women.

5. Job creation - promotion of labour intensive projects; and

6. Training and education that is responsive to skill requirements in the economy. Abdalla (1999).

Abdalla (1999) noted that the most obvious candidates for empowerment among the citizens of Botswana are the disabled, the children, the elderly, women, the poor, the unemployed, and even the environment which has been degraded by human actions. Each of those candidates according to him is either inherently powerless (the children, the elderly and the disabled) or have been disempowered by a higher authority or circumstance (women, the poor, racial minorities, and the environment. To design an economic empowerment strategies, it is necessary to first identify the individuals or groups that need to be 
empowered and then to understand the source of their disempowerment. A strategy to empower the private sector will necessarily be different from a strategy to empower women.

Abdalla (1999) further said that most women in general and especially poor women in the rural areas are closed and brought up in the culture of silence. Women are treated like second class citizens. They have no control over resources, be it physical resources (like real assets, land, water, and forests); intellectual resources. (Knowledge, information, and ideas); financial resources (money, access to credit); and the self (that unique combination of intelligence, creativity, self -esteem and confidence) nor do they have control over ideology, which means the ability to determine beliefs, values, attitudes, and ways of thinking and perceiving situations. Although some progress has been made in empowering women, these adverse conditions need to be corrected. It should also be noted that control over resources and ideology are so inseparably linked together that the loss of control over them leads to a vicious circle of more powerlessness within the individual and so within a group of individuals.

\section{The Concept of Cooperative}

Cooperative can be defined as voluntary and autonomous association of persons who came together, pull their resources (human and material) to solve their economic and social problems. Cooperative organization can also be defined as a group of persons who have pooled themselves and their resources on self-help, mutual, equitable and democratic basis to form a business enterprise, which seeks to solve the socio-economic problems of its members by directly providing them with goods services on their double capacity as either owner \customers or ownerlworkers of the cooperative enterprise.

Cooperative as defined by the International Cooperative Alliance's statement on the cooperative identity is an autonomous associations of persons united voluntarily to meet their common economic, social and cultural needs and aspirations through jointly owned and democratically controlled enterprise. A cooperative may also be defined as a business owned and controlled equally by the people who use its services or who work at it.
Cooperative can be single or multipurpose, primary, secondary or apex. It can be joint business or partial. Cooperative are based on the cooperative values of "self-help", self-responsibility, democracy and equality, equity and solidarity and the seven (7) cooperative principles

1. Voluntary and open membership.

2. Democratic member control.

3. Autonomy and independence.

4. Education, training and information.

5. Cooperation among cooperatives.

6. Concern for community.

In the tradition of their founders, cooperative members believe in the ethical values of honesty, openness, social responsibility and caring for others. Such legal entities have a range of unique social characteristics. Membership is open, meaning that anyone who satisfies certain non-discriminatory conditions may join. Economic benefits are distributed proportionally according to each member's level of participation in the cooperative, for instance by a dividend on sales or purchases, rather than divided according to capital invested. Cooperative may be generally classified as either consumer's cooperatives or producer's cooperatives.

The need for establishing cooperative enterprise is as follows:

1. "Individual small-scale farmers, industrialist, processor, marketers are too small to acquire and use efficiently the means of production.

2. They are too small to bargain for discount in the inputlfactor market and also to ensure a steady supply of these inputs.

3. They are unable to apply for loans individually and so may be constrained to resort to the informal sources where they may be exploited.

4. They are small to produce efficiently because of lack of specialization, small to take advantage of economies of scale hence production unit are not utilized.

5. They are unable to organize and collect the market information that is essential for efficient planning, and without planning management becomes inefficient. 
There is no areas of human endeavour that cooperative cannot be formed unless the members decided otherwise. What is not possible individually can be achieved jointly through cooperative. Women can form group farming cooperative society in the rural area for increased farm output by the members. This is done by engaging in communal farming on common land example Israeli moshaw. Women can equally form a processing cooperative for processing of their agricultural product, to add value to it and attract a better price for the goods. This will empower the women economically.

\section{Empowering Women through Cooperative}

Empowering women through cooperative according to Kokanova (2009) is to improve the socio-economic conditions of rural women and their families. Government has made effort to empower women's cooperative member by training cooperative member on micro credit financing as well as on how to boost agricultural production and their access to local market. The aim of empowering women through cooperative is to increase the capacity of the cooperatives to achieve a higher and more sustainable income. The government will work closely with women's cooperative, specifically identified as dynamic but with vulnerable members (Kokanova 2009). Sourbani (2009) suggests that in order to integrate the vast majority of poor women with the main stream of the society, our government has introduced measures to create social and economic awareness among the woman. Certainly, such measures have improved their standard of living. Cooperative, which is social and economic in character has been recognized as the most suitable institutions to undertake such tasks for the women. She also said that after rapid industrialization of their country India, women are actively participating in economic activities and they are not mere 'house wises" looking after house hold responsibilities. Involvements of women cooperative are practical program for raising the status of women in the society on a very large -scale especially in those echelons of our society where our help and assistance are needed most.

Atta (1990) opines that women have proven to the world today that they are assets for attaining sustainable and equitable global empowerment. He further argued that there is need to emphasize that women are agent of social change. In the past, it was even believed in Nigeria that women were less endowed than men, and that women was merely seen as chattels to be owned whose abiding responsibility laid home as kitchen manager and child bearing agent for the society. Attah however noted that the major constraints confronting low income people is that a large percentage of women lack group based support, credit and technical assistance.

Yaye (2010) argues that, if the women cooperative members are empowered and encouraged to embark on agricultural production, processing and marketing, the cooperative enables the women to be active in community development, participate in decisionmaking and improve their living standard. Vulnerable women are encouraged to create and join cooperative to increase their income. As they become economically empowered within the house hold, they are also less likely to surfer domestic violence.

Women could be used as proxy for economic empowerment in the sense that empowering women economically means empowering the whole nation. FAO (1987) noted that women make up $60 \%-80 \%$ of the agricultural labour force and depending on the region produce two-third of the food crops. Empowering women economically has a multiplier effect, if women are empowered, their income level and standard of living would be transformed. The life of their house hold will change, and if the life all the households in the area changes, the life the entire community will also will be transformed. If the effect of empowerment of women transforms the life the people in the, it will also affect the entire local government area, state and the nation at large. The gross domestic product (GDP) of the country will also increase.

Moreover, Bidisha (2008) opined that women empowerment is a change in the context of a women's life, which enables her increase capacity for leading a fulfilled human life. Women empowerment is one of the essential factors that promote human development. Infact, empowered women can contribute to human development through house hold and community activities and at the same time progress in human development is expected to promote women empowerment through improved health, nutrition, education, social security, political freedom, availability of employment and decent standard of living.

He also noted that women education has important bearings on children's health and their survival. A 
study Cote de Voire reveals that in increased women share over house hold income leads to increased spending on human development items like food, health care etc.

Blumberg (2005) opined that economic empowerment of women are the key to achieve gender equality as well as wealth and well-being of a nation. Almaz (2006) argued that increased income controlled by women gives them confidence which helps them obtains a voice and vote in:

1. House hold decisions such as domestic well being decision, for instance, women tend to use income clout for more equitable decisions about sons daughters diet, education and health.

2. Economic decision: acquiring, allocating and selling assets.

3. Fertility decision: economically empowered women tend to have fewer children.

4. Land use and conservation decision: rural women tend to favour sustainable environment practices since they are usually the ones that collect the families' natural resources, such as water and fire wood.

She noted that women economic power also enhances the "wealth and well-being of nations. More so women who control their own income tend to have fewer children, and fertility rates have shown to be inversely related to national income growth. However, women are also generally more willing than male counterparts to send daughters as well as sons to school, even when they earn less than men.

Furthermore, women represent half of the world's population, and gender inequality exists in every nation on the planet. To discriminate and prevent half of humanity from reaching its full potentials is economic folly. Denying women and girls equality and fairness not only hurts them, but also hinder the rest of the society. Almaz(2006).

\section{Methodology}

The area of the study is Awka south local government area of Anambra state. It is predominantly an agrarian community with many industrial establishment and institution of higher learning especially federal university, Nnamdi Azikiwe University. The head quarter of Awka south is Awka and also the state capital of Anambra state. There are eight (8) autonomous communities in the local government area. They are Awka, Amawbia, Nibo, Nise, Isiagu,
Mbaukwu, Umuawulu and Okpuno. Trading and farming are some of the occupation of the people The population of this study is all registered women cooperative in Awka south local government area, which is twenty-three (23) in number. The total membership strength of those women cooperative is six hundred and five (605). The total membership strength of the women cooperative in those rural communities is 326 , using simple percentage, twenty percent $(20 \%)$ of the total members of six selected women cooperative was used. $20 \%$ of 326 is 65 therefore 65 members of the women cooperative is our sample size and questionnaire was administered to them.

In this research, the analytical methods was used to investigate the outline objectives includes descriptive statistics such as frequency distribution (number and percentage) to facilitate effective comparison. In analysing the socio -economic characteristics of members, activities and functions of women cooperative and the effect on their income level, frequency model was used. Frequency distribution by number and percentage of respondents was also used to turn the qualitative characteristic into numerical forms.

Likert scale analysis was used to examine the perception of member on how cooperative services have brought about an enhancement to their economic well-being as represented by income. Further analysis was under taken to measure the effects of cooperative services such as credit extension, input supply, marketing, processing agricultural production etc on their income. To accomplish this, a multiple regression analysis was employed. The chosen model is linear and of the ordinary least square (OLS) type the specification of this model is as follows:

$\mathrm{Y}=\mathrm{Bo}+\mathrm{b} 1 \times 1+\mathrm{b} 2 \times 2+\mathrm{b} 3 \times 3+\mathrm{b} 4 \times 4+\mathrm{b} 5 \times 5+\mathrm{b} 6 \times 6+\mathrm{b} 7 \times 7+\mathrm{b}$ $8 \times 8+b 9 \times 9+b 10 \times 10+b 11 \times 11+e i$ where $\mathrm{Y}=$ total income of the members in 2009 in naira.

$\mathrm{X} 1=$ marital status of the member.

$\mathrm{X} 2=$ occupation of the member.

$\mathrm{X} 3=$ age of the member.

$\mathrm{X} 4=$ educational level of the member.

$\mathrm{X} 5=$ family size of the member

$\mathrm{X} 6=$ total value of agricultural product marketed through women cooperative in 2009 in naira.

$\mathrm{X} 7=$ total value agricultural product processed through women cooperative in 2009 in naira. 
International Journal of Trend in Scientific Research and Development (IJTSRD) ISSN: 2456-6470

$\mathrm{X} 8=$ amount of input purchased through women cooperative in 2009 in naira.

$\mathrm{X} 9=$ total amount of money obtained as loan through women cooperative in 2009.

$\mathrm{X} 10=$ total value of agricultural product produced through women cooperative in 2009 in naira.

$\mathrm{X} 11=$ the number of times the members of women cooperative received advices from the extension officers.

Bo $=$ intercept

$\mathrm{Ei}=$ error term

\section{Data Presentation and Analysis}

To generate data for analysis, the researcher distributed sixty-five questionnaires which was filled and returned. The data are in two sections, section A and $\mathrm{B}$, section $\mathrm{A}$ is the members socio-economic characteristic while section B is on the effect of cooperative activities and functions on the income and standard of living of members of women cooperative in the area. The data were presented in the tables below.

Section A: member's socio-economic characteristics.

Table 1 - Socio-economic profile of respondents

\begin{tabular}{|c|c|c|}
\hline Response & Frequency & Percentage \\
\hline \multicolumn{3}{|c|}{ Marital status } \\
\hline single & 2 & $3 \%$ \\
\hline married & $\begin{array}{r}09 \\
-\quad 49\end{array}$ & $75 \%$ \\
\hline widow & 14 & $22 \%$ \\
\hline Total & 65 & $100 \%$ \\
\hline \multicolumn{3}{|c|}{ Occupation } \\
\hline Civil Servant & 8 & $12.3 \%$ \\
\hline Farmer & 51 & $78.4 \%$ \\
\hline Trader & 6 & $9.2 \%$ \\
\hline Total & 65 & $100 \%$ \\
\hline \multicolumn{3}{|c|}{ Age } \\
\hline 20-30 years & 6 & $9 \%$ \\
\hline 31-40years & 12 & $18 \%$ \\
\hline $41-50$ years & 25 & $38 \%$ \\
\hline 5land above & 22 & $34 \%$ \\
\hline Total & 65 & $100 \%$ \\
\hline \multicolumn{3}{|c|}{ Educational Level } \\
\hline FSLC or Below & 20 & $31 \%$ \\
\hline O Level GCE $\backslash S S C E$ & 34 & $52 \%$ \\
\hline $\mathrm{ND} \backslash \mathrm{NCE}$ & 10 & $15 \%$ \\
\hline $\mathrm{BSC} \backslash \mathrm{HND}$ & 1 & $2 \%$ \\
\hline MSC and above & - & - \\
\hline TOTAL & 65 & $100 \%$ \\
\hline
\end{tabular}

\begin{tabular}{|c|c|c|}
\hline Response & Frequency & Percentage \\
\hline \multicolumn{3}{|c|}{ Number of children } \\
\hline 1 child & 2 & $3.1 \%$ \\
\hline 3 children & 10 & $15 \%$ \\
\hline 5 children & 22 & $34 \%$ \\
\hline 6 children & 21 & $32 \%$ \\
\hline $7 \&$ above & 10 & $15 \%$ \\
\hline Total & 65 & 100 \\
\hline \multicolumn{3}{|c|}{ Type of Cooperative they belong to. } \\
\hline Farmer's multipurpose & 10 & $15 \%$ \\
\hline Consumer coop. & nil & nil \\
\hline Multipurpose coop. & 50 & $77 \%$ \\
\hline Producer's coop. & 5 & $8 \%$ \\
\hline Total & 65 & 100 \\
\hline
\end{tabular}

Source: field survey 2010

In the table one, 49 respondents which is $75 \%$ are married, 2 respondents which represents $3 \%$ are single while 14 respondents which represents $22 \%$ are widow. This shows that majority of the women in the area are married and if empowered economically, they will be useful instrument for development. Also 8 respondents representing $12.3 \%$ are civil servant, and 51 respondents which represents $78 \%$ was farmers while 6 respondents are traders which are $9.2 \%$. This shows that majority of the women in Awka south local government area are farmers, so empowering women in the area through agricultural cooperative or farmers multipurpose cooperative will be successful. More so, 6 respondents which represent 9\% are within the ages of 20-30 years, 12 respondents representing $18 \%$ are in the age bracket of $31-40$ years while 25 respondents which are $38 \%$ were within $41-50$ years and 22 respondents representing 34\% are within the ages of 51 and above. This shows that the women are mostly in their active age and they can participate effectively and efficiently to success of their cooperative enterprise. However, 20 respondents which were $31 \%$ had FSLC or below, 34 respondents representing 52\% had GCElSSCE O'level, 10 respondents which were $15 \%$ had ND $\backslash$ NCE while 1 respondent had B.Sc.|HND which is $2 \%$. This shows that women in Awka south local government are not well educated; therefore adoption of modern agricultural technique will be a problem.Never the less, 2 respondents which represents $3.1 \%$ had 1 child, 10 respondents which represents $15 \%$ had 3 children, while 22 respondents representing $34 \%$ had 5 children and 21 respondents which is $32 \%$ had 6 children, 10 
International Journal of Trend in Scientific Research and Development (IJTSRD) ISSN: 2456-6470

respondents which is $15 \%$ had 7 children and above. This shows that women in the area usually have many children and they will be helpful in their farm during farming season.

Table 4.8: agricultural product marketed through
women cooperative
\begin{tabular}{|l|c|c|}
\hline response & frequency & percentage \\
\hline agree & 22 & $34 \%$ \\
\hline Strongly agree & 41 & $63 \%$ \\
\hline disagree & 2 & $3 \%$ \\
\hline Strongly disagree & nil & nil \\
\hline Total & 65 & 100 \\
\hline
\end{tabular}

Source: field survey 2010

As shown in the table above, 22 respondents representing $34 \%$ agreed that marketing of their product through women cooperative improve their income. 41 respondents which is $63 \%$ strongly agreed that it really improved their income, while 2 respondents which is $3 \%$ are of the opinion that it did not improve their income. This shows that women can be empowered economically through cooperative.

Table 4.9: profitability of processing agric product through cooperative

\begin{tabular}{|l|c|c|}
\hline \multicolumn{1}{|c|}{ Response } & Frequency & Percentage \\
\hline Agree & 6 & $9 \%$ \\
\hline Strongly agree & 38 & $58 \% \mathrm{~V}$ \\
\hline Disagree & 21 & $32 \%$ \\
\hline Strongly disagree & nil & nil \\
\hline Total & 65 & 100 \\
\hline
\end{tabular}

\section{Source: field survey 2010}

In table 4.9: above 6 respondents which is $9 \%$ agree that processing through women cooperative is profitable. 38 respondents representing 58\% strongly agreed that processing their produce through cooperative highly improved their income, while 21 respondents which are $32 \%$ disagreed that processing did not improve their income, from the oral interview with the members, they said that they are not into processing. This generally shows that processing of agricultural products through cooperative is positively related to income.
Table 4.10: cost reduction of input purchased through cooperative

\begin{tabular}{|l|c|c|}
\hline \multicolumn{1}{|c|}{ Response } & Frequency & Percentage \\
\hline Agree & 45 & $69 \%$ \\
\hline Strongly agree & nil & Nil \\
\hline Disagree & 16 & $25 \%$ \\
\hline Strongly disagree & 4 & $6 \%$ \\
\hline Total & 65 & 100 \\
\hline
\end{tabular}

\section{Source: filed survey 2010}

As shown in the table above, 45 respondents which represent $69 \%$ agreed that the amount of input purchased through women cooperative was at a lower price, 16 respondents which is $25 \%$ disagreed that it not at a lower cost or rather that they have not purchased any input from their cooperative. This shows that majority of the women in the area acquire their input through women cooperative because of cost reduction.

\section{Regression Result}

The large values of F-statistic (967.388) appear to indicate that the explanatory variables included in the model collectively have significant influence on income of the women cooperative in Awka south local government area. The R2 at .994 and adjusted$\mathrm{R} 2$ at .993 suggest that over 90 percent variations in the income are explanatory variables included in the model.

\begin{tabular}{|c|c|c|c|c|}
\hline Model & coefficients & St error & $\begin{array}{c}\text { t- } \\
\text { statistic }\end{array}$ & $\begin{array}{c}\text { Level } \\
\text { of } \\
\text { sign. }\end{array}$ \\
\hline (constant) & 2648.096 & 4551.429 & .582 & .563 \\
\hline $\mathrm{X} 1$ & 1063.545 & 989.630 & 1.075 & .287 \\
\hline $\mathrm{X} 2$ & -167382 & 720.908 & -232 & .817 \\
\hline X3 & I83.579 & 110.280 & 1.665 & .102 \\
\hline $\mathrm{X} 4$ & -317032 & 157.801 & -2.009 & .049 \\
\hline X5 & -854.265 & 508.022 & -1.682 & .008 \\
\hline $\mathrm{X} 6$ & .977 & .041 & 23.728 & .000 \\
\hline $\mathrm{X} 7$ & .008 & .006 & 1.346 & .004 \\
\hline $\mathrm{X} 8$ & .173 & .043 & 4.073 & .000 \\
\hline $\mathrm{X} 10$ & -002 & .038 & -.056 & .956 \\
\hline $\mathrm{R} 2$ & .994 & & & \\
\hline Adj. R2 & .993 & & & \\
\hline F-statistic & 967.388 & & & \\
\hline $\mathrm{N}$ & 65 & & & \\
\hline DW & 1.431 & & & \\
\hline
\end{tabular}

Source: filed survey 2010 
As shown in table 4, educational level has marginal contribution of -317.032 with a $t$ - ratio of -2.009 which is significant at 5\% level of significance. However, it has inverse relationship with income of women cooperative in Awka south. This shows that as their educational level increases, they no longer participate in farming activities rather they may engage themselves as civil servants.

Family size has marginal contribution of -854.265 with t-ratio of -1.682 which is significant at $1 \%$ level of significance. However, it has inverse relationship with the income of those women cooperative in the area .In my apriori expectation, it is expected to be positively related, this could be that most families engage the services of hire labour in their farm because their children are either in school or are apprenticed out to learn trading or artesian job.

The value of agricultural product marketed through women cooperative has a marginal contribution of .977. The t- value is 23.728 which are significant at 1 percent level. This result also shows that marketing through cooperative is positively related to income of the members, as the value of the product marketed increases, the income of the member's increases. Cooperative members are encouraged to market their farm product through cooperative.

The value of agricultural product processed through women cooperative has a marginal contribution of .008 . The $\mathrm{t}$-value is 1.346 which is highly significant at 1 and 5 percent level of probability. This result also shows that value of processed product is positively related to income, as the processed product increases, income increases. Thus cooperative are encouraged to process their farm product in other to boost their income.

The amount of input procured has a marginal contribution of .173 . The t-value is 4.037 which are highly significant at $1 \%$. Thus there is a high degree contribution of input procured by the members of women cooperative to their income. This result also shows that input has a positive relationship with income that is as the amount of input increases, income level increases. Thus input is relatively significant determinant of income of women cooperative societies in Awka south.

The tables and discussions indicates that among the independent variables hypothesized as having significant effect on income of the women cooperative, the following are to be accepted and considered as strong of income level:

1. Total value of agricultural products marketed through women cooperative.

2. Total value of agricultural product processed through women cooperative

3. Amount of input purchased through women cooperative.

\section{Conclusion and Policy Implications}

The result of the study shows that marketing through cooperative is positively related to income of the members, as the value of the product marketed increases, the income of the members' increases. More so, the value of processed product is positively related to income, as the processed product increases, income increases. There is also high degree contribution of input procured by the members of women cooperative to their income. This result also shows that input has a positive relationship with income that is as the amount of input increases, income level increases. Thus input is relatively significant determinant of income of women cooperative societies in Awka south. Cooperative members are encouraged to market and process their farm product through cooperative in other to boost their income. Income was used as a proxy for women empowerment through cooperative in the area because if women in the area are empowered economically, other aspects of empowerment follow. If women's income is high, they will also be socially, politically, psychologically, culturally and religiously empowered. Nevertheless, women empowerment is not without challenges.

\section{REFERENCE}

1. Abadalla G. (1999): Citizen Economic Empowerment in Botswana: Concepts and Principles. Botswana Institute for Development Policy Analysis (BIDPA)

2. Attah J. (1990). The Role of cooperative in women in Development in Nigeria, Paper presented at $1^{\text {st }}$ cooperative forum, Abuja.

3. Almaz, N. (2006) Economic empowerment women; First women intellectual forum.

4. Bidisha, M. (2008) women empowerment in Assam "A human Development Approach. Dissertation work. 
5. Blumberg, R. L. (2005): “women economic empowerment as the magic portion of development. "Paper presented at the $100^{\text {th }}$ annual meeting of the America sociological association, Philadelphia.

6. Cheryle, C. (1999) Journal of extension w.w.w. Joe org.

7. Chilokwu, I. D. O. and Obi (2009); Rural urban migration and Enterprise Development: A case study of Awka North and South local government Area of Anambra State "In journal of policy and development studies. Vol. 1 no 3 November.

8. Conger, J. \& Kanungo, R. (1988) Behavioral Dimensions of Charismatic Leadership. In: Conger, J. A., Kanungo, R. N. and Associates, Eds., Charismatic Leadership: The Elusive Factor in Organizational Effectiveness, Jossey Bass, San Fransico, 78-97.

9. FAO (1990), women in Agricultural development: FAO's plan of action. A publication of the food and agricultural organization (FAO) of the world.

10. FAO (1987), Reports of workshop on effectiveness of agricultural Extension service in reaching rural women in African food and
Agricultural organization (FAO) Harere, Zimbabwe, October.

11. Friedman J. (1992). : Empowerment: the Politics of Alternative Development. ISBN:978-1-55786300-3. July 1992 Wiley- Blackwell.

12. Kokanova, N. (2009); nora. kokanova@ Unifem. Org.

13. Onugu, C. U. (2006); "Dynamics of rural-urban migration as perceived by Co- operators in Anambra state: implications for Development. Vol.1 no 1, November.

14. Rapopport, J. (1984); Studies in empowerment: Introduction to the issue. Prevention in human services.

15. Sourbani, P. (2009); the role cooperative in empowering. Umebali, E. E. \& Agu F. (2009); Understanding the concept, stages and Principles of cooperative group formation: paper Presented at $1^{\text {st }}$ Cooperative Economics \& Management workshop, Nnamdi Azikiwe University, Awka.

16. Yaye, M. (2010); Empowering Women through Agriculture. The Gbalin Women Cooperative in Liberia. 